糖尿病患者の免疫学的研究

第顺報

一一览糖疗病患者心抗䤚状腺抗体

宗都大学医学部第 2 内科

塎阊研五，鍋谷登，桜美 武彦
大阪赤十字病院内科
久 野 昭 太郎

\title{
Thyroglobulin and microsomal antibodies in diabetes mellitus in childhood.
}

\author{
Kengo NAGAOKA, Noboru NABEYA, Takehiko SAKURAMI \\ 2nd Department of Internal Medicine, Faculty of Medicine, Kyoto University
}

\author{
Shotaro KUNO \\ Osaka Red Cross Hospital
}

The purpose of our study was to determine the incidence of thyroid antibodies in diabetes mellitus in childhocd and to discuss the correlation between thyroid antibodies and insulin antibodies.

The sera of 50 children with diabetes mellitus and 437 children as disease controls were tested by thyroglobulin and microsome coated tanned red cell hemagglutination test (Fuji Zoki Co. Tokyo).

One of the 50 children with diabetes mellitus(2\%) was positive with antithyroglobu. lin antibodies and eleven (22\%) were positive with antimicrosomal antibodies compared to $0.4 \%$ and $1.1 \%$ respectively in 437 disease controls.

To clarify the association of insulin antibodies and thyroid antibodies in diabetes mellitus in childhood, insulin antibodies were demonstrated by using a modified method described by Wright.

One of the 33 children with negative insulin antibody $(2.8 \%)$ was positive with antithyroglobulin antibodies and eight $(24 \%)$ were positive antimicrosomal antibodies.

None of the 17 children with positive insulin antlbodies were positive with antithy. roglobulin antibodies and three (18\%) were positive with antimicrosomal antibodies.

No evident correlation was observed between antithyroid antibodies and insulin antibodies. 


\section{序言}

小児桾尿病患者のわが国での報告 ${ }^{1223)}$ はその発生頻度に执いて小児10万名に 9〜11 名の割合で存在し，し 加むその率は次第に熄加していると言われている。従来，小児糖尿病患者のほとんどがインスリン注射を絶 对的に必要之する若年型糖尿病之考えられていたが最近では成人之同じく化学的糖尿病やインスリン非依存

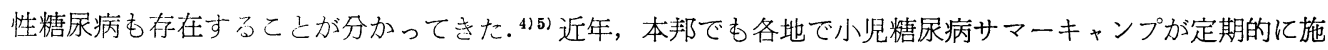
行され小児糖尿病に対する関心屯高まり患者数屯かなり多いととが分かってきたが成人の糖尿病に比較する とその病態や治療の面での研究はかなり立ち遅机ている。一方, 糖尿病と自己免疫との関係を示㕹する報告 が最近，欧米では相次いでいる.

すなわち糖尿病患者のうち絶対的にインスリンを必要とするインスリン依存性の患者ではインスリン非依 存性の患者に比べ抗甲状腚抗体, 抗胃壁細胞抗体, 抗副謷抗体等の藏器特異的な血中自己抗体の出現率が極 めて高いことが報告されている3 ${ }^{67778)}$. 本邦におけるこの種の研究では糖尿病患者 507 名につき抗甲状腺抗体 在検索したわ机わ机の報告9 が最初であるがその際インスリン依存性の糖尿病患者の抗甲状腺抗体は非依存 性の患者に比べその出現頻度は極めて高く，またこれら抗甲状腺抗体とインスリン抗体の間に何ら因果関係 が認奶られなかった ${ }^{10)}$. しかしながらその場合に対象とした糖尿病患者は全例18歳以上であったので，今回 小児糖尿病サマーキャンブの施行等により15歳未満で発症した 20 歳までの小児楉尿病患者 50 名 (平均 11 歳) につき抗甲状腺抗体を検索する機会を得たのでそれ々同時にインスリン抗体を測定しこれら両者の関係につ き检汒を加えたので郝告する。

\section{対象および方法}

(対象)

対象之した小児煻沓病患者は第 4 回近幾地区小児糖尿病サマーキャンプに参加した 46 名を含め計 50 名, そ の内訳は 8 歳から14歳まで平均11藏の男子 21 名, 女子は 3 歳から 20 歳まで平均12歳の 29 名から成り男女比は $1: 1.38$ であり全例インスリンによる治潦を受けていた。慢性甲状腚炎を合併していると思われた 1 名は対 象より除外した，尚，対照としていわゆる小児正常健康者の血清採取が実際上困難であったため，何らかの 诉え在有し本院外来を受彰しもしくは入院した 0 歳から19歳まで平均8.4歳の男子232名, 女子 205 名, 計437 名を対照とした。甲状腺機能九進症や慢性甲状腺炎等の甲状腺疾患を有する者は予め除いた。

\section{(方法)}

1. Thyroglobulin 抢よび Microsome に対する抗体価は Thyroid test（以下 TG と略す）および Microsome test (以下 MS と略す) (富士藏器 K.K. 東京)により Microtiter Kit (Cooke Engineering Co.) のV plate を用いて測定した.

2. インスリン抗体の測定は Wright の変法"11によった。 ${ }^{125}$ I-インスリンはSephadex G-75 chromatographyにより $0.1 \mathrm{M}$ 燐酸緩衝液 $\mathrm{pH} 7.4$ で溶出し純化したものを用いた. 抗体結合 ${ }^{125} \mathrm{I}$ イインスリン(B) 上遊離 ${ }^{125} \mathrm{I}$-インスリン(F)の分離にはセルロース吸着法を用い, Parkerの補正式 ${ }^{12}$ に準じB corrected/F を 求めた。

\section{成 績}

Table 1 は小児糖尿病患者50名の抗甲状腺抗体の陽性率を示すが Thyroid test (TG) 陽性者は 1 名のみ

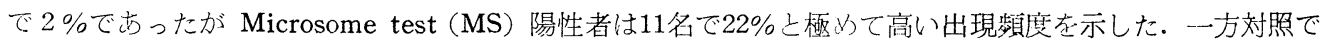
は TG，MS 陽性者はそれぞ机2名 $(0.4 \%) ， 5$ 名 $(1.1 \%)$ で古った。

尚, 対照とした 437 名のうち抗甲状腺抗体が陽性を示した 5 名は 1 歳の急性リンパ性白血病の女子, 17 歳 のボタロー管開存症の女子，12歳の気管支炎の男子，14歳の心室中隔欠損症の女子，16歳の特発性侧惢症の 男子であった。乙机ら 5 名共, 甲状腺腫存有せず本人および家族には抗甲状腺抗体の出現し易い疾患は全く 認められなかった。 
Table 2 は小児糖尿病患者を男女別に抗甲状腺 抗体の出現頻度をみたものであるが男子の TG お よび MS 陽性率はそれぞれ 0\%，19\%，女子の TG および MS 陽性率は 3\%，24\%と女子の方 が男子よりもやや高い陽性率を示した.

Fig. 1 は小児糖尿病患者の Microsome test の抗体価を年龄別にみたものであるが最も高い抗 体価は $10 \times 2^{10}$ であった. またこの図から見る限 りやや加齢之共に陽性者の抗体価が上昇している ように見受けられるが，20歳以上のインスリン依 存性の若年型糖疗病患者では特に加齢亡抗体価に は相関関係は見られなかった。尚，図には示さな かったが Thyroid test 陽性者は14歳の女子 1 名のみでありその抗体価は $10 \times 2^{4}$ であった.

Table 3 は小児糖尿病患者50名につきインスリン抗体を測定しインスリン抗体陰性および陽性の 2 群に分 け，その各々に抢ける抗甲状腺抗体の陽性率を示すがインスリン抗体陰性患者33名では TG および MS の 陽性率は $2.8 \% ， 24 \%$ を示したのに比ベインスリン抗体陽性患者 17 名ではそれぞれ $0 \%$ ，18\%といずれるイ ンスリン抗体陽性患者での抗甲状腺抗体陽性率が特に高いという結果は得られず，むしろインスリン抗体陰 性患者において高い陽性率を示した。 このようにインスリン抗体と抗甲状腺抗体の出現との間には特に因果 関係を見い出すことが出来なかった．次に特に表には示さなかったがインスリン需要量と抗甲状腺抗体の間 にあ何ら因果関係が見られなかった。

Table 1. Incidence of thyroid antibodies in diabetes mellitus in childhood.

\begin{tabular}{|c|c|c|}
\hline Group & $\begin{array}{l}\text { Disease controls } \\
\text { no. tested } 437\end{array}$ & $\begin{array}{l}\text { Diabetes mellitus } \\
\text { in childhood } \\
\text { no. tested } 50\end{array}$ \\
\hline Thyroid test Positive & $2(0.4 \%)$ & $1(2 \%)$ \\
\hline Microsome test Positive & $5(1.1 \%)$ & $11(22 \%)$ \\
\hline
\end{tabular}

Table 2. Incidenc of thyroid antibodies in diabetes mellitus in childhood.

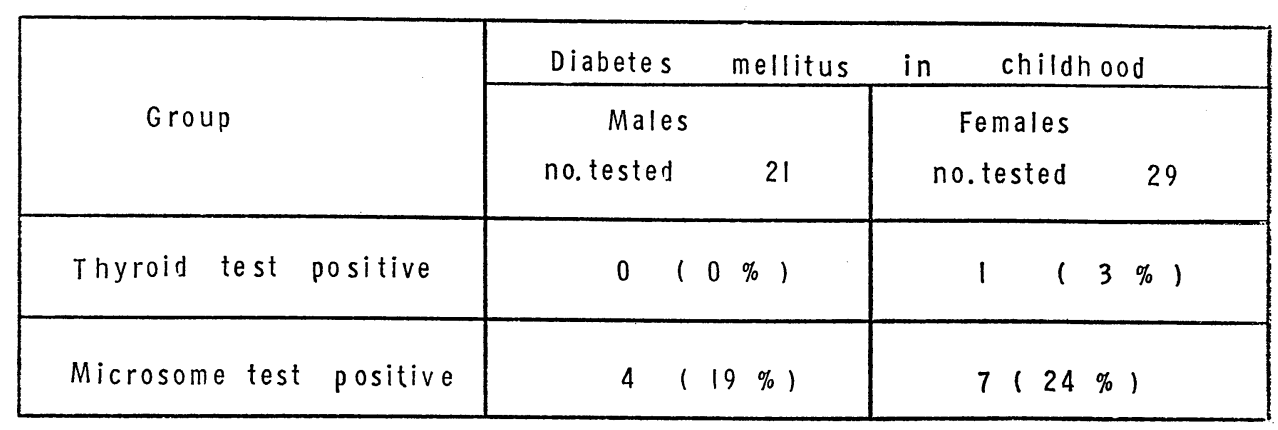


Table 3. Incidence of thyroid antibocdies in diabes mellitus in childhood.

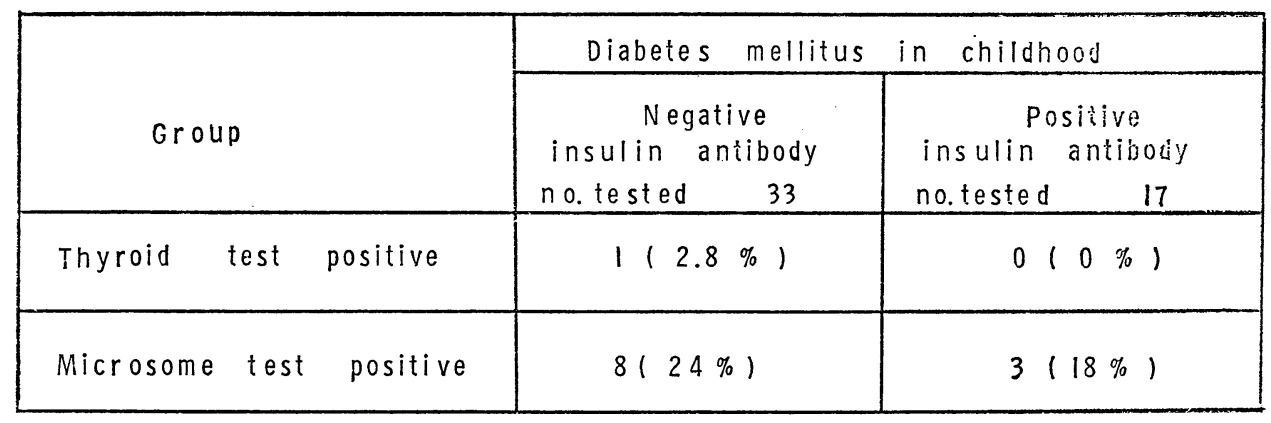

今回，小児糖尿病患者では対照とした小児に比べ抗甲状腺抗体の出現頻度が極めて高いという結果を得た が欧米では既に Pettit ら ${ }^{13)}$ が16歳以下の小児糖尿病患者の抗甲状腺抗体を螢光抗体法により検索し正常小 児 178 名では $1.1 \%$ の陽性率であったが小児糖尿病患者58名では22\%の陽性率であったとしている.

我々は Pettit らの螢光抗体法による方法とは異なりタンニン酸処理赤血球凝集反応により検索したが, 対照小児の抗マイクロゾーム抗体陽性率が $1.1 \%$ あっったのに比し, 小児糖尿病患者では $22 \%$ 高い陽性率 を示し方法の違いはあれ Pettit らの報告に殆しど一致する成績を得た．既に我々はインスリン非依存性の 成人の糖尿病患者 473 名での TG 抢上び MS 陽性率は, そ机ぞれ $2.3 \%, 4.4 \%$ とうう成績を得ているの でこ机之比較しても小归糖病患者では $2 \%, 22 \%$ あるから特に MS において極めて高い陽性率を示し た.

今回は対照として何らかの訴えを有し外来に来院むしくは入院した患者 437 名を対象とし 437 名中, 陽性 者は 5 名のみでありてれら陽性者は全例甲状腺腫を有せず，また本人および家族には抗甲状腺抗体の出現し 易い疾患は全く認めら机なかった。屯し正常健康小児を対照とするならこの TG, MS それぞれ $0.4 \%, 1.1$ \%上いう陽性率はもっと低くなることが予想されるのでてれら小児糖尿病患者の抗甲状腺抗体の陽性率は極 めて高い事が改めて立証されると思われる. 尚, 打れわれが20２9歳の正常健康人 740 名に施行した TG お よび MS の出現頻度はそれぞれ $1.2 \%, 1.6 \%$ であった ${ }^{14)}$. 抗甲状腺抗体は慢性甲状腺炎や甲状腺機能立進 症等の甲状腺疾患以外の自己免疫疾患, すなわち重症筋無力症 ${ }^{15)}$, 全身性エリテマトーデス, 沉発性強皮症, ルポイド肝炎 ${ }^{16)}$ 等々にも高い頻度で出現する事が知られているが，てれらの疾患についての我々の成績をみ る上慢性甲状腺炎や甲状腺機能六進症での抗甲状腺抗体, すなわち TG 又は MS の一方むしくは両方共に 陽性を示した者の出現率はいずれも $62 \%$ あ゙り ${ }^{17}$ ，それ以外の上述した自己免疫疾患では $19 \%$ \% 33\%の陽性 率を示した。一方，すでに報告した18歳以上のインスリン依存性糖尿病患者の抗甲状腺抗体陽性率 $29.4 \%$, および今回の15歳未満で発症したインスリン依存性の小児糖尿病患者の抗甲状腺抗体陽性率 $22 \%$ 上記各種 自己免度疾患之同じ程度の陽性率を示した.

この様に徒来, 糖尿病が自己免疫疾患であるとは考えら机ていなかったのであるが，今回の成績ではイン スリンを絶対的に必要とする小坚糖尿病および若年型糖尿病では, 自己免疫と何らかのかかわり合いを有し ているという可能性が示唆された。今回, 対象とした小児桾尿病患者は全例インスリン依存性の患者であ ったが既に述べたように最近，小児糖尿病患者の中にも化学的糖㽷病やインスリン非依存性糖尿病の存在す る事が分かっている.すなおち Martin ら としている. 従って今回は検索し得なかったが, インスリン非依存性の小児糖尿病患者の抗体についても今 後十分に比較検討さ机なければならない，次にインスリン依存性糖尿病患者での血中自己抗体の高い出現率 はインスリン注射によって異種抗体の産生が惹起さ机るの上同時にある種の自己抗体の産生を容易にするよ 
うな機序が作働するようになるのではないかという事が一応問題になり得ようが抗甲状腺抗体とインスリン 抗体の関係は成人の場合之同じく何ら因果関係が見られなかった。梴っててれらインスリン依存性糖尿病患 者ではインスリン注射に影響されて自己抗体が産生されたのではなくて，Irvine らの主張するように何ら かの遺厷的機序により自己抗体が患者の流血中に既に存在していた事が考えられる. 最近 Nissley ら ${ }^{181}$ は家 族調査を行い抗甲状腺抗体, 抗胃壁細胞抗体, 抗副腎抗体が陽性を示す若年型糖尿病患者の両親や同胞は, これらの抗体が陰性を示す患者の両親や同胞よりもこれら抗体の出現頻度がかなり高いことを示したとし ているのでこれら患者の家族の抗体の検索は遺伝学的にも興味ある課題である. 又, 最近では糖尿病患 者についての 細胞性免疫の面からの成績により 糖尿病の病因に自己免疫機序を想定する研究者が少なくな い.

すなわち Nerup ら ${ }^{197}$ は146例の糖尿病患者, またCudworth ら ${ }^{20)}$ は 100 名の糖尿病患者につき HL-A 抗 原の検索を行い両者共, 急性発症の若年型糖尿病では他の自己免疫疾患と同じく HL-A 8，W 15 が多い事

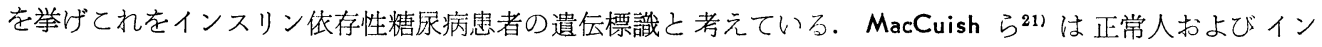
スリン依存性患者をコントロール良好な患者とコントロール不良の患者との 3 群に分け， Tリンパ球と Bリ ンパ球とを測定したが特にての三つのグループに有意差は見られなかったが PHA に対する反応をみてみる とコントロール不良の糖尿病患者ではコントロール良好な患者に比し PHA に対する反応性の低下をみたと している．従って彼らはこの事実は遺伝的な免度学的異常よりもむしろ代謝障害起因していると考えてい る.

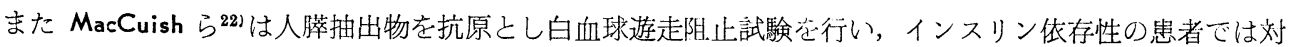
照に比し陽生率が高かったが，ラットの肝ミトコンドリアや牛インスリンを抗原として使用した場合には遊 走阻止は見られなかったとしている. このように細胞性免疫の面からの糖尿病患者の種々の研究以外に従来 より若年型糖尿病の急性型では膵島にリンパ球浸潤があるととが Gepts ${ }^{23)}$ ，LeCompte ら ${ }^{24)}$ により報告さ れているがての組織像がウイルス感染時のそれとよく似ているた以糖尿病のウイルス病因論がむる。すなお ち，若年型糖尿病患者では Coxsackie B4 抗体価の高值がみられたとする報告がその代表的なものである が Steinke ら ${ }^{25)}$ は何らかのウイルスが脺島のB 細胞に直接作用することにより抗原が迮脱し抗体産生が薏起 され組織傷害が生ずるというウイルス感染をひき金とする自己免疫機序を一つの可能性として挙げている. 今回, ウイルス抗体価の測定は施行していないが糖尿病患者での血液, 膵臓ともにウイルスの分離培盖には 現在までのととろ成功していないのでインスリン依存性糖尿病の病因を考える上にウイルス説は根拠にそし いと言わざるを得ない.

従ってウイルス感染が直接ひき金の役目を果たしているか否かは不明であるにしてもインスリン依存性糖 尿病患者では自己免疫機序により膵島が傷害されインスリン分泌障害をきたし梼尿病が発症するのではない かという推論が成り立つ、いずれにしても今回の成績ではインスリン依存性の小児桾尿病患者で 抗甲状 腺抗体の出現頻度が極めて高く既に報告されている各種自己免疫疾患における抗甲状腺抗体の出現頻度 と比較対照してみても糖尿病と自己免疫とのかかわり合いを強く示咙していると考えざるを得ない結果を得 た.

\section{結 語}

1）インスリン依存性の小児桾尿病患者50名のうち Thyroid test は $2 \%$, Microsome test は22\%の陽 性率が得られた。一方対照小児437名の Thyroid test 抢よび Microsome test の陽性率はそれぞれ0.4\%， 1.1\%であった.

2) Thyroid test, Microsome test 両テスト共, 陽性を示した者は男子よりもやや女子の方が高い出現 率を示した.

3）インスリン抗体と抗甲状腺抗体との間には何ら因果関係が見られなかった.

4）小児桾尿病患者では他の各種自己免疫疾患之同じく抗甲状腙抗体の高い陽性率を示した. 
深瀬政市教授及び倉八博之先生の御指導を深謝します。また第 4 回近畿地区小児糖尿病サマーキャンプで, この種研究 目的を理解し御協力頂いた, 国立大阪病院糖尿病センター泉寬治先生, 大阪市立大学小児科一色玄先生, 大阪市立小児保 健センター村上勉先生に感謝します.

本研究費の一部は厚生省特定疾患橋本病調查研究班より援助を受けた.

\section{文献}

1）細迫有昌，松山恒雄：八幡製鉄所從業員家族の全小児における糖尿病の頻度. 糖尿病, 9: 160-161, (1966).

2）三木英司, 丸山博 : 日本の若年発症糖尿病. 糖尿病, $15: 38-42,(1972) . \quad 3 ）$ 武田倬 : 山陰地方 における小児糖尿病. 綜合臨林, $24: 1833-1837$, (1975). 4 4) Martin, M.M., Martin, A.L.A. : Obesity, hyperinsulinism and diabetes mellitus in childhood. J. Pediat., $82: 192-201$, (1973).

5) Drash, A. : Diabetes mellitus in childhood. J. Pediat., $78: 919-941$, (1971). 6) Irvine, W.J., Clarke, B.F., Scarth, L., Cullen, D. R., Duncan, L. J.P. : Thyroid and gastric autoimmunity in patients with diabetes mellitus. Lancet, $2: 163-168,(1970) . \quad 7$ ) Nerup, J., Binder, C. : Thyroid, gastric and adrenal autoimmunity in diabetes mellitus. Acta. endocri, $72: 279-286$, (1973). 8) Ungar, B., Stocks, A. E., Martin, F. I. R., Whittingham, S and Mackay, I.R. : Intrinsic-factor antibody, parietal-cell antibody, and latent pernicious anemia in diabetes mellitus. Lancet, $2: 415-$ 417, (1968). 9）長岡研五, 鍋谷登, 桜美武彦, 深瀬政市, 久野昭太郎 : 糖尿病患者の抗甲状腺抗体, 日内分泌誌, 51 : 573-579, (1975). 10) 長岡研五, 倉八博之, 鍋谷登, 桜美武彦, 深瀬政市, 久野 昭太郎 : 糖尿病患者の免疫学的研究一第二報一抗甲状腺抗体とインスリン抗体との関連一日内分泌誌 $51: 878-$ 886, (1975). 11) Wright, P. H., Mallaisse, W. J. : A simple method for the assay of guinea pig anti-insulin serum. Diabetologia, $2: 178-188$, (1966). 12) Parker, M.L., Mariz, I.K., Daughaday, W.H. : Resistance to human growth holmone in pituitary dwarfism : Clinical and immunologic studies. J. Clin. Endocri, $24: 997-1004$, (1964). $\quad$ 13) Pettit, M.D., Landing, B.H., Guest, G.M. : Antithyroid antibody in juvenile diabetics. J. Clin. Endocri, $21: 209-210$, (1961). 14）長岡研五, 桜美武彦, 深頼政市, 小川逢三：正常健康者における抗甲状腺抗体の出現頻度, 日内分速誌, 51 : 98-102, (1975). 15）長岡研五, 難波秀弘, 野口貞子, 鍋谷登, 小川博遊, 桜美武彦, 深瀬政市, 西谷裕：重症筋無力症患者の抗甲状腺抗体について，内科宝函，22:185-190，(1975). 16）長岡研五, 小川博遊, 鍋谷 登, 桜美武彦, 川口義夫 : 肝疾患における抗甲状腺抗体执よび抗核抗体と HB 抗原との関 連・肝藏, $17: 41-46$, (1976). 17) 長岡研五, 桜美武彦, 深瀬政市 : 甲状腺疾患に打ける抗甲状腺抗 体, 内科宝函, $22: 119-125$, (1975). 18) Nissley, S.P., Drash, A.L., Blizzard, R.M., Sperling, M., and Childs, B : Comparison of juvenile diabetes with positive and negative organ specific antibody titers. Diabetes, $22: 63-65$, (1973). $\quad$ 19) Nerup, J., Platz, P,. Anderson, O.O., Christy, M., Lyngse, J., Poulsen, J. E. : HL-A antigens and diabetes mellitus. Lancet, II : 864866. (1974). 20) Cudworth, A. G., Woodrow, J. C. : HL-A system and diabetes mellitus. Diabetes, 24 : 345-349, (1975). $\quad$ 21) MacCuish, A.C., Urbaniak, S.J., Campbell, C.J., Duncan, L. J. P., Irvine, W. J. : Phytohemagglutinin transformation and circulating lymphocyte subpopulations in insulin-dependent diabetic patients. Diabetes, $23: 708-712$. (1974).

22) MacCuish, A. C., Jordan, J., Campbell, C. J., Duncan, L. J. P., Irvine, W. J. : Cell-mediated immunity to human pancreas in diabetes mellitus. Diabetes, $23: 693-697$, (1974).

23) Gepts, W. : Pathologic anatomy of the pancreas in juvenile diabetes mellitus. Diabetes, 14 : 619-633, (1965). 24) LeCompte, P.M. : "Insulitis" in early juvenile diabetes. Arch. path, $66: 450-457$, (1958). $\quad 25)$ Steinke, J., Taylor, K.W : Viruses and the etiology of diabetes :

Diabetes, $23: 631-633$, (1974). 